DOI: $10.46340 /$ eppd.2020.7.4.24

Oleksandr Borovytskyi, Judge

ORCID ID: https://orcid.org/0000-0003-0891-6366

Seventh Appeal Administrative Court, Ukraine

\title{
DISCRETIONAL NATURE OF THE POWERS \\ OF THE HIGH COUNCIL OF JUSTICE IN THE FORMATION OF JUDICIARY
}

\author{
Олександр Боровицький, суддя \\ Сьомий апелячійний адміністративний суд, Україна

\section{ДИСКРЕЦІЙНИЙ ХАРАКТЕР ПОВНОВАЖЕНЬ ВИЩОЇ РАДИ ПРАВОСУДДЯ $З$ ФОРМУВАННЯ СУДДІВСЬКОГО КОРПУСУ}

The article examines the features of the implementation of the powers by the High Council of Justice in the formation of the judiciary, approaches to understanding the concept of «discretion» and its signs. The author has proved that discretionary powers are an evaluative concept; the issue of assigning certain powers to discretionary ones must be considered in the context of each individual case of exercising the powers by a state body, and the preconditions that determine the discretionary nature of the powers of the High Council of Justice in the formation of the judiciary are highlighted. It is determined that the discretionary nature of the powers of the High Council of Justice in the formation of the judiciary is conditioned by the following prerequisites: the ability to form their own assessment of the circumstances surrounding the candidate for the position of judge and his/her personal qualities; the priority of the internal belief of each member of the High Council of Justice over the internal beliefs of the candidates for the position of a judge; the possibility of ambiguous interpretation of the concepts of «integrity» and "professional ethics» in the circumstances that indicate the dishonesty of the judge.

Keywords: the High Council of Justice, the Constitutional Court of Ukraine, discretion, judiciary, powers, formation.

Постановка проблеми. Механізм формування суддівського корпусу, наділення та припинення повноваженнями суддів, починаючи зі створення незалежної України, зазнавав змін, впроваджувалися різні підходи до формування суддівського корпусу різної ефективності.

Так, 15 грудня 1992 року в межах діючої на той час судово-правової реформи набув чинності Закон України «Про статус суддів», який регулював діяльність судової системи, вимоги, які надають право особі на зайняття посади судді, порядок добору та обрання (призначення) суддів, порядок і строки чергових атестацій професійних суддів.

3 метою створення механізмів забезпечення незалежності суддів у лютому 1994 року було прийнято Закон України «Про кваліфікаційні комісії, кваліфікаційну атестацію і дисциплінарну відповідальність суддів судів України», відповідно до якого основним призначенням вказаних комісій було «забезпечення формування суддівського корпусу, здатного кваліфіковано, сумлінно та неупереджено здійснювати правосуддя на професійній основі, а також визначення рівня професійної підготовленості суддів та розгляд питань їх дисциплінарної відповідальності» (стаття 1).

Конституційним договором, підписаним між Президентом України й Верховною Радою України 18 травня 1995 року, був змінений порядок призначення суддів на посади, який ставав більш регламентованим та формалізованим, зокрема, голови Верховного Суду України та Вищого арбітражного суду України й судді цих судів призначалися Верховною Радою за поданням Президента України, усі інші судді призначалися Президентом за поданням Міністерства юстиції, погодженим, відповідно, із Верховним Судом України або Вищим арбітражним судом України, але повноваження кваліфікаційних комісій не зазнали змін. 
Значним кроком до створення сучасної судової системи, забезпечення незалежного функціонування судової влади в Україні стало створення з прийняттям 28 червня 1996 року Конституції України конституційного органу Вищої ради юстиції (далі - ВРЮ), до відання якої згідно статті 131 Конституції України, зокрема, унесення подання про призначення суддів на посади або про звільнення їх із посад.

Згодом після внесення змін до Конституції Законом № 1401-VIII від 02.06.2016 року та прийняття Закону № 1798-VIII від 21.12.2016 року ВРЮ замінила Вища рада правосуддя (далі - ВРП) 3 певним чином модернізованими повноваженням.

Надзвичайно громіздкий, надмірно ускладнений та економічно не доцільний як 3 теоретичного, так і практичного погляду механізм призначення особи на посаду судді був змінений, але $з$ практичної точки зору чинний механізм не усунув повністю проблеми щодо зловживань при доборі та призначенні суддів, прозорості й справедливості в реалізації суддями професійної кар'єри ${ }^{1}$.

Аналіз останніх джерел та публікацій. Підгрунтя дослідження склали праці, присвячені дослідженню міжнародно-правових стандартів судоустрою та судочинства, питанням порядку формування суддівського корпусу, таких учених і практиків, як О.Б. Абросимова, С.В. Боботов, В.Д. Бринцев, О.В. Гончаренко, О.С. Захарова, О.В. Карпушова, С.В. Ківалов, М.І. Клеандров, В.М. Колесниченко, В.В. Кривенко, М.М. Кухта， В.М. Лебєдєв， І.Є. Марочкін， Ю.М. Михєєнко, Л.М. Москвич， С.В. Прилуцький， Р.В. Романюк， О.В. Саленко, І.Л. Самсін, М.П. Селиванов, Л.В. Скомороха, Н.С. Слободяник, В.С. Стефанюк, В.А. Туманов, В.І. Шишкін та ін.; В.С. Сгоровою здійснено порівняльний аналіз досвіду формування суддівського корпусу України і зарубіжних країн.

Актуальним питанням діяльності органів, що забезпечують формування суддівського корпусу, безпосередньо приділяв увагу I.С. Марочкін, зарубіжний досвід судового управління та можливості його використання при реформуванні судової системи України вивчався С.Ю. Обрусною.Питання правового статусу Вищої ради юстиції досліджувалися О.В. Гончаренком, І.В. Назаровим, С.О. Халюком, особливості їі формування - В.М. Колесниченком, грунтовний аналіз статусу Вищої ради юстиції як органу контрольної влади та перетворення її на Вищу раду правосуддя проведений Д.А. Опаленком.

Питання дискреції повноважень досліджувалися як вітчизняними дослідниками (В.М. Венгером, Ю.М. Грошевим, О.Г. Крижовою, А.С. Макаренко, М.А. Погорецьким, М.Б. Рісним, O.I. Сеньків, M.I. Смоковичем, I.А. Тітком та ін.), так і закордонними, зокрема, необхідно відзначити дослідження Р. Алексі, А.В. Дайсі; О.С. Ігнатьєва, В.В. Подгруши, І. Рихтера, Г. Шупперта.

Мета статті - виявити особливості реалізації повноважень Вищої ради правосуддя 3 формування суддівського корпусу.

Виклад основного матеріалу. Якщо згадати повноваження ВРЮ, то в своєму Рішенні від 16 жовтня 2001 року №14-рп/2001 Конституційний Суд України, проаналізувавши положення чинної Конституції України та положення Закону України «Про Вищу раду юстиції»прийшов до висновку, що ВРЮможе вносити подання Президенту України тільки про перше призначення на посаду професійного судді строком на п'ять років. А за змістом пункту 1 частини першої статті 131 Конституції України право внесення подань Верховній Раді України про обрання суддів безстроково та призначення суддів на адміністративні посади в судах загальної юрисдикції на ВРЮ не поширюється ${ }^{2}$.

У справі №1-7/2011 предметом дослідження на предмет відповідності Конституції України були повноваження Вищої ради юстиції призначати суддів на адміністративні посади в судах та звільняти їх з цих посад, чим, на думку суб'єкта конституційного подання, розширено іiі конституційну компетенцію та не передбачене в Конституції України повноваження щодо перегляду та скасування рішень Вищої кваліфікаційної комісії суддів України про відмову у рекомендуванні

\footnotetext{
${ }^{1}$ Центр Разумкова (2013). Судова реформа в Україні: поточні результати та найближчі перспективи. Інформаційно-аналітичні матеріали до Фахової дискусї на тему «Судова реформа 2010 р.: чи наближає вона правосуддя в Україні до європейських норм і стандартів?» 4 квітня 2013 р., 60.

$<$ http://razumkov.org.ua/upload/Sudova_reforma_2013.pdf> (2020, червень, 18).

${ }^{2}$ Рішення у справі за конституційним поданням Вищзої ради юстиції щуодо офіційного тлумачення положення пункту 1 частини першої статті 131 Конституції України стосовно внесення Вищяю радою юстиції подань про призначення суддів на посади (справа про призначення суддів), 2001 (Конституційний Суд України). Офіційний сайт Верховної Ради України <https://zakon.rada.gov.ua/laws/show/v014p710-01\#Text> (2020, червень, 18).
} 
кандидата для обрання на посаду судді безстроково та притягнення судді до дисциплінарної відповідальності. КСУ не вбачив невідповідності Конституції України вказаних положень .

Після конституційної реформи 2016 року, стаття 128 Конституції визначила, щопризначення на посаду судді здійснюється Президентом України за поданням Вищої ради правосуддя в порядку, встановленому законом.

3 цього приводу слід зазначити, що у пункті 14 Доповіді, присвяченій призначенню суддів (Венеція, 16-17 березня 2007 р.), Венеціанська Комісія відзначила, що якщо Президент має діяти лише в межах подання незалежної ради суддів, призначення суддів Президентом країни не видається процедурою, що може створити проблемиㄹ․

Положення про ВРП відповідають також Рекомендації NR 94(12), в якій підкреслюється, що «орган, який приймає рішення про відбір і кар'єру суддів, повинен бути незалежним від уряду та адміністрації. Для того, щоб гарантувати його незалежність, мають бути встановленими правила, що забезпечують, наприклад, обрання членів цього органу з кола суддів, а також положення, згідно з яким сам орган вирішує питання своєї процедури» ${ }^{3}$; статті 9 Загальної (Універсальної) хартії суддів, ухваленої 17 листопада 1999 року Центральною Радою Міжнародної Асоціації Суддів у Тайпеї (Тайвань), яка передбачає, що обрання судді на посаду має відповідати об'єктивним та прозорим критеріям і базуватися суто на його професійній кваліфікації. Якщо обрання на посаду не відбувається іншим шляхом згідно з встановленою та глибоко вкоріненою традицією, то таке обрання має здійснювати незалежний орган, що містить достатню кількість представників судової влади ${ }^{4}$.

Стосовно цього в Європейській хартії про закон «Про статус суддів» також зазначено: «відносно будь-якого рішення, пов'язаного з добором, прийомом на роботу, призначенням, підвищенням судді на посаді або звільненням з посади, закон про статус суддів передбачає втручання органу, незалежного від виконавчої й законодавчої влади, у якому принаймні половина тих, хто $€$ членами даного органу, є суддями, вибраними своїми колегами відповідно до методів, що гарантують найширше представництво судової влади» ${ }^{5}$.

В Пекінських тезах стосовно принципів незалежності суддівюридичної асоціації країн азійського татихоокеанського регіону (LAWASIA),прийняті провідними діячами в галузіправосуддя в LAWASIA, а також суддями зАзії та тихоокеанського регіону в Пекіні в1995 року та схвалені на засіданні радиLAWASIA в 2001 році, наголошується, що для досягнення суддямисвоїх цілей та реалізації своїх функцій суддіповинні обиратися на засадахкомпетентності, неупередженості танезалежності (п. 11), недискримінації (п. 13), а спосіб обрання суддів повинен гарантуватиобрання найбільш кваліфікованогокандидата на посаду (п. 12)

Принцип суддівської незалежностібезпосередньо пов'язують із професійнимдобором суддів і Рекомендації Латімер Хаус щодо парламентаризму та незалежності суддівства в країнах загального права, прийняті назустрічі представників парламентськоїасоціації, асоціації магістратів та суддів,асоціації адвокатів та освітньої юридичноїасоціації країн загального права 19 липня 1998 рокуㄱ,

\footnotetext{
${ }^{1}$ Рішення у справі за конституиійним поданням 54 народних депутатів України щзодо відповідності Конституиії України (конституціийності) окремих положень законів Украӥни «Про судоустрій і статус суддів», «Про Вищу раду юстииії (справа про повноваження державних органів у сфері судоустрою)», 2011 (Конституційний Суд України). Офічійний сайт Верховної Ради Украӥни <http://www.ccu.gov.ua/docs/626> (2020, червень, 18).

${ }^{2}$ Верховний Суд України (2007). Доповідь Свропейської комісії «За демократію через право» (Венеиіанської комісії) щзодо призначення суддів. Доповідь ухвалено Венеціанською комісією на 70 пленарному засіданні (м. Венеція, 16-17 березня 2007 р.) <http://www.scourt.gov.ua/clients/vsu/vsu.nsf> (2020, червень, 18).

${ }^{3}$ Рекомендація про незалежність, дієвість та роль суддів, 1994 (Комітетом Міністрів Ради Свропи). Міжнародні стандарти незалежності суддів. Київ: Поліграф-Експрес, 86-90.

4 Загальна (Універсальна) хартія судді, 1999 (Міжнародна Асоціація Суддів). Міжнародні стандарти незалежності суддів. Київ: Поліграф-Експрес, 35-38.

${ }^{5}$ Свропейська хартія про закон «Про статус суддів», 1998 (Рада Європи). Міжнародні стандарти незалежності суддів. Київ: Поліграф-Експрес, 91-95.

${ }^{6}$ Пекінські тези стосовно принциипів незалежності суддів юридичної асоиіації країн азійського та тихоокеанського регіону, n. 12, 1995 (LAWASIA). Офіційний сайт Верховної Ради Украӥни

$<$ https://zakon.rada.gov.ua/laws/show/995_j78\#Text> (2020, червень, 18).

${ }^{7}$ Рекомендаиії Латімер Хаус щฺодо парламентаризму та незалежності суддівства в краӥнах загального права, 1998 (Парламентська асоціація, Асоціація магістратів та суддів, Асоціація адвокатів, Освітня юридична асоціація країн загального права). Міжнародні стандарти незалежності суддів. Київ: Поліграф-Експрес, 177-179.
} 
в яких наголошується, процеспризначення повинен здійснюватися такимчином, щоб гарантувати незалежність таналежний інтелектуальний рівеньпретендентів, обраних для призначеннясуддів на всіх рівнях.

В науковій літературі немає уніфікованого визначення поняття «суддівського корпусу», виходячи з етимології слова«корпус» («сукупність осіб якогось одного фаху, службового становища тощо» ${ }^{1}$, треба погодитися з Р.А. Крусян, що під ним треба розуміти «сукупність осіб, які здійснюють правосуддя та мають однаковий статус» ${ }^{2}$.

На думку С. Прилуцького, механізм формування суддівського корпусу є безперервним циклом руху професійного судового складу, який містить у собі порядок набуття права й відповідний йому порядок припинення судової служби, певний упорядкований процес кадрового забезпечення судової влади, що включає правові механізми набуття та припинення суддями повноважень ${ }^{3}$.

Повноваження ВРП щодо формування суддівського корпусу та його зміни регулюються главою 2 «Участь у формуванні суддівського корпусу» (ст.ст. 36-38), главою 6 «Звільнення судді 3 посади» (ст.ст. 55-57), главою 8 «Тимчасове відсторонення судді від здійснення правосуддя» (ст.ст. 62-69), главою 9 «Переведення суддів» (ст.ст. 70-72) Закону України «Про Вищу раду правосуддя» ${ }^{4}$.

Процедурні питання здійснення вказаних повноважень регулюються главами 10 «Участь у формуванні суддівського корпусу», 15 «Звільнення судді з посади», 16 «Припинення відставки судді», 17 «Звільнення судді з посади за особливих обставин», 19 «Тимчасове відсторонення судді від здійснення правосуддя», 21 «Переведення суддів» Регламенту ВРП.

Згідно частині 2 статті 36 ЗУ «Про Вищу раду правосуддя» ВРП ухвалює рішення щодо внесення Президентові України подання про призначення судді на посаду за результатами розгляду рекомендації Вищої кваліфікаційної комісії суддів України.

Попередній розгляд рекомендації здійснює доповідач, визначений у порядку автоматизованого розподілу, та готує висновок, який передає до відповідного структурного підрозділу секретаріату Ради для формування порядку денного Ради (п.10.2 Регламенту ВРП).

За результатами розгляду рекомендації Вищої кваліфікаційної комісії суддів України Рада та висновку доповідача ВРП може також ухвалити рішення про відмову у внесенні подання Президентові України про призначення на посаду судді, таке рішення може бути ухвалене відповідно до підстав, зазначених у пункті дев'ятнадцятому статті 79 Закону України «Про судоустрій і статус суддів».

Аналогічне положення міститься у частині 4 статті 37 3У «Про Вищу раду правосуддя».

При цьому Касаційний адміністративний суд у складі Верховного Суду вказав у своєму Рішенні у справі П/9901/293/18 від 7 лютого 2018 року, що норма підпункту 1 частини 19 статті 79 Закону № 1402-VIII «Про судоустрій і статус суддів» містить подвійну клаузулу:

1) наявність обгрунтованого сумніву щодо відповідності кандидата критерію доброчесності чи професійної етики - як окрему підставу для відмови у внесенні подання Президентові України про призначення судді; та

2) наявність інших обставин, які можуть негативно вплинути на суспільну довіру до судової влади у зв'язку з таким призначенням - як окрему підставу для відмови у внесенні відповідного подання ${ }^{5}$.

У п.10.4 Регламенту ВРП окремо зазначається, що підстави, зазначені у підпункті 1 частини дев'ятнадцятої статті 79 Закону України «Про судоустрій і статус суддів», ВРП визначає, керуючись власною оцінкою обставин, пов'язаних із кандидатом на посаду судді, та його особистих якостей.

Треба зазначити, що підстави прийняття ВРП рішення про відмову у внесенні подання Президентові України про призначення на посаду судді значно відрізняються від аналогічного повноваження ВРЮ, яка могла прийняти таке рішення тільки «уразі встановлення порушень порядку,

\footnotetext{
${ }^{1}$ Білодід, І. К. (ред.) (1973). Словник украӥнської мови. Академічний тлумачний словник в 11 томах. Київ: Наукова думка, 4, 300.

${ }^{2}$ Крусян, Р. А. (2018). Реформування системи судоустрою України: досвід, сучасність, тенденції: дисертація на здобуття наукового ступеня кандидата юридичних наук. Одеса: Національний університет «Одеська юридична академія», 168.

${ }^{3}$ Прилуцький, С. В. (2002). Формування судового корпусу: національний та світовий досвід. Актуальні проблеми політики: Збірник наукових працьь, 13-14, 560.

4 Закон про Вищу раду правосуддя, 2017 (Верховна Рада України). Відомості Верховної Ради України, 7-8, 50.

${ }^{5}$ Рішення у справі П/9901/293/18, 2018 (Касаційний адміністративний суд у складі Верховного Суду України). Сдиний державний реєстр судових рішень <http://reyestr.court.gov.ua/Review/72089229> (2020, червень, 18).
} 
які призвели або могли призвести до неправильних результатів добору», але, на відміну від ВРП, також могла визначити «дії Вищої кваліфікаційної комісії суддів України, необхідні для усунення наслідків цих порушень» (частина 4 статті 29 ЗУ «Про Вищу раду юстиції» в редакції від 04.06.2015 року).

Тобто ВРП виступає «юридичним фільтром» у процесі призначення суддів на посади, іiі завдання - 3'ясувати наявність будь-яких юридичних перешкод для заняття посади судді, а також аспекти морально-етичної поведінки особи, здатність їі здійснювати правосуддяя ${ }^{1}$, і несе політичну й моральну відповідальність перед суспільством за якісний стан суддівського корпусу, а фактично й за стан правосуддя в країні.

Велика Палата Верховного Суду зазначила, що повноваження ВРП стосовно оцінювання обставин, пов'язаних із кандидатом на посаду судді, та його особистих якостей є дискреційними та виключною компетенцією іiі як уповноваженого органу, постійно діючого у вітчизняній системі судоустрою (Постанова Великої палати Верховного Суду від 9 квітня 2018 року, справа № 800/546/17 $(\Pi / 9901 / 293 / 18))$.

Визначення «дискреційних повноважень» в законодавстві міститься тільки в діючій Методології проведення антикорупційної експертизи, затвердженій Наказом Міністерства юстиції України від 24.04.2017 №1395/5, яка визначає їх як можливість на власний розсуд визначити повністю або частково вид і зміст управлінського рішення, яке приймається, або можливість вибору на власний розсуд одного з декількох варіантів управлінських рішень, передбачених нормативно-правовим актом, проєктом нормативно-правового акту.

Що стосується доктрини, то можна виділити два основних підходи до визначення «дискреції». Щодо першого, то мова йде про ототожнення термінів «дискреція» та «розсуд», при чому основною правовою категорією виступає саме «розсуд», та тлумачяться через термін «вибір».

В цьому контексті інтерес представляють поняття та ознаки дискреції, що виділені О.С. Ігнатьєвим. По-перше, дослідник, викоритовуючи терміни «дискреція» та «розсуд» як тотожні та проаналізувавши сутність і зміст розсуду як правової загальнотеоретичної категорії, тлумачить дискрецію через термін «вибір», який одночасно позначає стан, процес і результат, відповідно, на його думку, дискреція - «це вибір уповноваженого публічно-правового суб'єкта, обмежений об'єктивними факторами (межами), що полягає в знаходженні і прийнятті оптимального рішення правового питання». По-друге виділяє сукупність необхідних та достатніх ознак розсуду (дискреції): публічно-правовий суб'єкт; об'єктивно обмежена правова свобода; право (правомочність); інтелектуально-вольова діяльність, яка полягає в пошуку і прийняття оптимального рішення правового питання².

Інший підхід виходить з розуміння «дискреції» через поняття «право (повноваження)», «діяльність».

Так, частина авторів право (повноваження) публічно-правового суб'єкта відносять до центральних ознак дискреції, інші лише доповнюють ним аспект активності, але в будь-якому випадку праву (повноваженням) кореспондує саме діяльність, яка як ознака дискреції не завжди називається прямо (3.М. Лукманова, О.А. Папкова).

Згідно Рекомендацій Комітету Міністрів Ради Європи № $\mathrm{R}(80) 2$ щодо здійснення адміністративними органами влади дискреційних повноважень, прийнятої Комітетом Міністрів 11.03.1980 року на 316-й нараді, дискреційні - це такі повноваження, які адміністративний орган, приймаючи рішення, може здійснювати з певною свободою розсуду, тобто, коли такий орган може обирати з декількох юридично допустимих рішень те, яке він вважає кращим за даних обставин.

За даними Єдиного державного реєстру судових рішень, перші посилання на Рекомендації з'явилися в рішеннях 2010 року, а насьогодні такі рішення набули масового поширення в адміністративно-судовій практиці, але посилання мають одноманітний характер.

Заслуговує на увагу і позиція М. Смаковича, що дискреція включає в себе не тільки вольовий елемент (вільний розсуд), а й інтелектуальний морально-правовий, який визначає використання

\footnotetext{
${ }^{1}$ Скомороха, Л. В. (2010). Організаційно-правові та процедурні аспекти практики формування суддівського корпусу в Україні. Вісник Вищої ради юстииіï, 1, 32.

${ }^{2}$ Игнатьев, А. С. (2015). Усмотрение как правовая общетеоретическая категория и алгоритм его отраслевого анализа (на примере сферы судебного конституционного контроля): дисертация на соискание научного степня кандидата юридичних наук. СПБ: Северо-Западный институт управления $<$ https://disser.spbu.ru/files/disser2/1085/disser/8mFtWLb820.pdf> (2020, червень, 18).
} 
дискреційних повноважень зі здоровим глуздом, що передбачає не стільки логічний порядок дій, скільки розумну сталість правопорядку, мораль, суспільні традиції, загальновизнані принципи і цінності, включаючи суто внутрішню мотивацію.

Відповідно, на його думку, з якою не можна не погодитися, з теоретичної точки зору дискреційні повноваження - це встановлені законами права і обов'язки владних суб'єктів, які визначають ступінь самостійності їх реалізації з урахуванням принципу верховенства права i полягають в застосуванні ними адміністративного розсуду при здійсненні дій і прийнятті рішень ${ }^{1}$.

Не зважаючи на різноманітність підходів до розуміння «дискреції», «розсуду», всі дослідники наголошують на необхідності чітко визначати межі дискреції, межі дозволеності відходу від визначеного порядку.

Таку ж позицію займає й Європейський суд з прав людини. Якщо узагальнити, то ЄСПЛ розглядає застосування національного закону в конкретній юридичній ситуації через призму меж дискреційних повноважень державних національних органів, які застосовували закон при вирішенні юридичного конфлікту, та безпосередньо відповідність вчинених дій ззастосування закону в дискреційних межах (наприклад, рішенняБаклі (Buckley) проти Великої Британії від 25 серпня 1996 року, рішення у справі Фадєєва (Fadeyeva) проти Росії від 9 червня 2005 року тощо).

Щодо дискреційних повноважень ВРП, то остання у межах здійснення власних повноважень наділена правом надавати загальну правову кваліфікацію судовим рішенням, які були прийняті певним суддею, при цьому обов'язковою умовою $\epsilon$ те, щоб ВРП не надавала оцінку саме процесуальним діям судді, не перевіряла законність постанови чи судового рішення, а лише оцінювала дії особи при здійсненні нею правосуддя у контексті їх відповідності статусу судді та можливих негативних наслідків у вигляді підриву суспільної довіри до суду.

У законодавстві України не конкретизовано, що саме слід вважати «іншими обставинами», які можуть негативно вплинути на суспільну довіру до судової влади у зв'язку з призначенням суддею, як необхідно тлумачити «доброчесність».

Аналіз рішень ВРП, судової практики Касаційного адміністративного суду, Верховного суду доводить, що висновок про наявність обставин, які свідчать про недоброчесність судді та можуть негативно вплинути на суспільну довіру до судової влади у зв'язку з призначенням особи на посаду судді ВРП може зробити з різних підстав, наприклад:

- ігнорування при постановленні постанови Конституції України та практики ЄСПЛ (рішення ВРП від 07 листопада 2017 року №3602/0/15-17);

- різкі відмінності у практиці застосування одних і тих самих положень матеріального закону протягом нетривалого часу, істотне відхилення від достатньо чітких і однозначних положень закону, які не можуть бути пояснені текстом судового рішення і супроводжуються звільненням осіб, які вчинили адміністративне правопорушення, від найбільш суворого стягнення, що їм загрожувало (рішення ВРП від 04 квітня 2019 року № 1044/0/15-19);

- факт притягнення до дисциплінарної відповідальності, навіть при наявності висновку дисциплінарного органу ВРП про те, що допущені суддею порушення були неумисними та не містили ознак істотного дисциплінарного проступку; форма вини і загалом наявність або відсутність у діях судді складу дисциплінарного проступку не мають вирішального значення (рішення ВРП від 20 червня 2017 року № 1638/0/15-17; від 07 листопада 2017 року № 3603/0/15-17) тощо.

При цьому як зазначається в Постанові Великої Палати Верховного Суду від 30 квітня 2020 року у справі № 9901/238/199 (п.9), оцінка ВРП дій судді у схожих ситуаціях не обмежується лише об`єктивними критеріями і оцінювання завжди має суб`єктивний характер. Тому той факт, що ВРП, реалізуючи свою конституційну функцію, неоднаково вирішила питання щодо суддів за ззовні подібних обставин, сам собою не може свідчити про протиправність, дискримінацію чи свавілля під час прийняття рішень (аналогічні висновки містить і п.67 постанови від 04 квітня 2019 року у справі № 800/551/17).

Відповідно до статті 38 ЗУ «Про Вищу раду правосуддя» рішення Вищої ради правосуддя про відмову у внесенні Президентові України подання про призначення судді на посаду може бути оскаржене та скасоване виключно з підстав, визначених пункту 21 статті 79 ЗУ «Про судоустрій і статус суддів».

\footnotetext{
${ }^{1}$ Смокович, М. (2015). Административная юстиция в вопросе дискреционных полномочий. Судебно-юридическая газета, 46 (314), 13 <https://sud.ua/ru/news/sud-info/84051-administrativnaya-yustitsiyav-voprose-diskretsionnikh-polnomochij-4c1b25> (2020, червень, 18).
} 
На сьогодні Великою Палатою Верховного Суду сформована стала позиція, що, вирішуючи спір про правомірність відмови ВРП внести подання про призначення судді на посаду, суд, надаючи йому юридичну оцінку, має повну юрисдикцію, яка не обмежується лише з`ясуванням наявності визначених ЗУ «Про судоустрій і статус суддів» формальних підстав, для скасування такого рішення, а й повинен також ретельно дослідити дотримання ВРП під час прийняття рішення пункту 3 частини 19 статті 79 Закону щодо його вмотивованості. При цьому оцінка Верховним Судом мотивів та обгрунтованості оскаржуваного рішення ВРП не $є$ втручанням уії дискреційні повноваження (постанова від 04 квітня 2019 року у справі № 800/551/17 (п.37), постанова від 27 червня 2019 року у справі № 800/291/17 (П/9901/100/18) (п.50), постанова від 30 квітня 2020 року усправі № 9901/238/19 (п.8)).

Висновки і пропозиції.Дискреційні повноваження - поняття оціночне, питання віднесення тих чи інших повноважень до дискреційних необхідно розглядати в контексті кожного окремого випадку реалізації повноважень державного органу.

Дискреційний характер повноважень ВРП при формуванні суддівського корпусу обумовлюється наступними передумовами:

- можливістю формування власної оцінки обставин, пов'язаних із кандидатом на посаду судді, та його особистих якостей;

- пріоритетом внутрішнього переконання кожного члена ВРП над внутрішнім переконанням кандидата на посаду судді;

- можливістю неоднозначного тлумачення понять «доброчесність» $\mathrm{i}$ «професійна етика» при встановлені обставин, які свідчать про недоброчесність судді та можуть негативно вплинути на суспільну довіру до судової влади у зв'язку з призначенням особи на посаду судді.

\section{References:}

1. Razumkov Center (2013). Sudova reforma v Ukrayini: potochni rezultaty ta nayblyzhchi perspektyvy. Informatsiyno-analitychni materialy do Fakhovoyi dyskusiyi na temu Sudova reforma 2010: chy nablyzhaye vona pravosuddya $v$ Ukrayini do yevropeyskykh norm i standartiv? 4 kvitnya 2013 [Judicial reform in Ukraine: current results and short-term prospects. Information and analytical materials for the Professional discussion on Judicial reform in 2010: does it bring justice in Ukraine closer to European norms and standards? April 4, 2013] $<$ http://razumkov.org.ua/upload/Sudova_reforma_2013.pdf> (2020, June, 18). [in Ukrainian].

2. Rishennya u spravi za konstytutsiynym podannyam Vyshchoyi rady yustytsiyi shchodo ofitsiynoho tlumachennya polozhennya punktu 1 chastyny pershoyi statti 131 Konstytutsiyi Ukrayiny stosovno vnesennya Vyshchoyu radoyu yustytsiyi podan pro pryznachennya suddiv na posady (sprava pro pryznachennya suddiv), 2001 [Decision in the case on the constitutional petition of the High Council of Justice on the official interpretation of the provision of paragraph 1 of part one of Article 131 of the Constitution of Ukraine concerning the submission by the High Council of Justice of petitions on appointment of judges (2001)]. (Konstytutsiynyy Sud Ukrayiny) [The Constitutional Court of Ukraine]. Ofitsiynyy sayt Verkhovnoyi Rady Ukrayiny [The official site of the Verkhovna Rada of Ukraine] <https://zakon.rada.gov.ua/laws/show/v014p710-01\#Text> (2020, June, 18). [in Ukrainian].

3. Rishennya u spravi za konstytutsiynym podannyam 54 narodnykh deputativ Ukrayiny shchodo vidpovidnosti Konstytutsiyi Ukrayiny (konstytutsiynosti) okremykh polozhen zakoniv Ukrayiny Pro sudoustriy i status suddiv, Pro Vyshchu radu yustytsiyi (sprava pro povnovazhennya derzhavnykh orhaniv u sferi sudoustroyu), 2011 [Decisions in the case on the constitutional petition of 54 people's deputies of Ukraine on compliance with the Constitution of Ukraine (constitutionality) of certain provisions of the laws of Ukraine On the Judiciary and the Status of Judges, On the High Council of Justice (case on powers of state bodies in the judiciary), 2011]. (Konstytutsiynyi Sud Ukrayiny) [The Constitutional Court of Ukraine]. Ofitsiynyy sayt Verkhovnoyi Rady Ukrayiny [The official site of the Verkhovna Rada of Ukraine] <http://www.ccu.gov.ua/docs/626> (2020, June, 18). [in Ukrainian].

4. Verkhovnyy Sud Ukrayiny (2007) [The Supreme Court of Ukraine (2007)]. Dopovid Yevropeyskoyi komisiyi Za demokratiyu cherez pravo (Venetsianskoyi komisiyi) shchodo pryznachennya suddiv. Dopovid ukhvaleno Venetsians'koyu komisiyeyu na 70 plenarnomu zasidanni (m. Venetsiya, 16-17 bereznya 2007) [Report of the European Commission for Democracy through Law (Venice Commission) on the appointment of judges. Report adopted by the Venice Commission at its 70th plenary session (Venice, 16-17 March 2007)] $<$ http://www.scourt.gov.ua/clients/vsu/vsu.nsf $>$ (2020, June, 18). [in Ukrainian].

5. Rekomendatsiya pro nezalezhnist, diyevist ta rol suddiv, 1994 [Recommendation on the Independence, Effectiveness and Role of Judges, 1994] (Komitet Ministriv Rady Yevropy) [Committee of Ministers of the Council of Europe]. Mizhnarodni standarty nezalezhnosti suddiv [International standards for the independence of judges]. Kyiv: Poligraf-Express, 86-90. [in Ukrainian]. 
6. Zahalna (Universalna) khartiya suddi, 1999 [General (Universal) Charter of Judges, 1999] (Mizhnarodna Asotsiatsiya Suddiv) [International Association of Judges]. Mizhnarodni standarty nezalezhnosti suddiv [International standards for the independence of judges]. Kyiv: Poligraf-Express, 35-38. [in Ukrainian].

7. Yevropeyska khartiya pro zakon Pro status suddiv, 1998 [European Charter of the Law on the Status of Judges, 1998] (Rada Yevropy) [The Council of Europe]. Mizhnarodni standarty nezalezhnosti suddiv [International standards for the independence of judges]. Kyiv: Poligraf-Express, 91-95. [in Ukrainian].

8. Pekinski tezy stosovno pryntsypiv nezalezhnosti suddiv yurydychnoyi asotsiatsiyi krayin aziyskoho ta tykhookeanskoho rehionu, 1995 [Beijing Theses on the Principles of Independence of Judges of the Asia-Pacific Law Association, 1995] (LAWASIA). Ofitsiynyy sayt Verkhovnoyi Rady Ukrayiny [The official site of the Verkhovna Rada of Ukraine] <https://zakon.rada.gov.ua/laws/show/995_j78\#Text> (2020, June, 18). [in Ukrainian].

9. Rekomendatsiyi Latimer Khaus shchodo parlamentaryzmu ta nezalezhnosti suddivstva v krayinakh zahalnoho prava, 1998 [Latimer House Recommendations on Parliamentarism and the Independence of the Judiciary in Common Law Countries, 1998] (Parlamentska asotsiatsiya, Asotsiatsiya mahistrativ ta suddiv, Asotsiatsiya advokativ, Osvitnya yurydychna asotsiatsiya krayin zahalnoho prava) [Parliamentary Association, Association of Magistrates and Judges, Bar Association, Educational Legal Association of Common Law Countries]. Mizhnarodni standarty nezalezhnosti suddiv [International standards for the independence of judges]. Kyiv: Poligraf-Express, 177-179. [in Ukrainian].

10. Bilodid, I. K. (ed.) (1973). Slovnyk ukrayinskoyi movy. Akademichnyy tlumachnyy slovnyk v 11 tomakh [Dictionary of the Ukrainian language. Academic explanatory dictionary in 11 volumes]. Kyiv: Naukova dumka, 4. [in Ukrainian].

11. Krusyan, R. A. (2018). Reformuvannya systemy sudoustroyu Ukrayiny: dosvid, suchasnist, tendentsiyi: dysertatsiya na zdobuttya naukovoho stupenya kandydata yurydychnykh nauk [Reforming the judicial system of Ukraine: experience, modernity, trends: dissertation for the degree of Candidate of Law.] Odesa: National University Odesa Law Academy [in Ukrainian].

12. Prylutskyi, S. V. (2002). Formuvannya sudovoho korpusu: natsionalnyi ta svitovyy dosvid [Formation of the judiciary: national and world experience]. Aktualni problemy polityky: Zbirnyk naukovykh prats [Current policy issues: A collection of scientific papers], 13-14, 558-564. [in Ukrainian].

13. Zakon pro Vyshchu radu pravosuddya, 2017 [Law on the High Council of Justice, 2017] (Verkhovna Rada Ukrayiny) [Verkhovna Rada of Ukraine]. Vidomosti Verkhovnoyi Rady Ukrayiny [Information of the Verkhovna Rada of Ukraine], 7-8, 50. [in Ukrainian].

14. Rishennya u spravi P/9901/293/18, 2018 [Decision in case P / 9901/293/18, 2018] (Kasatsiynyy administratyvnyy sud u skladi Verkhovnoho Sudu Ukrayiny) [Administrative Court of Cassation within the Supreme Court of Ukraine]. Yedynyy derzhavnyy reyestr sudovykh rishen [Unified state register of court decisions]

$<$ http://reyestr.court.gov.ua/Review/72089229> (2020, June, 18). [in Ukrainian].

15. Skomorokha, L. V. (2010). Orhanizatsiyno-pravovi ta protsedurni aspekty praktyky formuvannya suddivs'koho korpusu v Ukrayini [Organizational, legal and procedural aspects of the practice of forming a judicial corps in Ukraine]. Visnyk Vyshchoyi rady yustytsiyi [Bulletin of the High Council of Justice], 1, 31-41. [in Ukrainian].

16. Ignatyev, A. S. (2015). Usmotreniye kak pravovaya obshcheteoreticheskaya kategoriya i algoritm yego otraslevogo analiza (na primere sfery sudebnogo konstitutsionnogo kontrolya): disertatsiya na zdobuttya naukovogo stupenya kandidata yuridichnikh nauk [Discretion as a legal general theoretical category and an algorithm for its sectoral analysis (using the example of the sphere of judicial constitutional control): dissertation on the scientific level of the candidate of legal sciences]. St. Petersburg: North-West Institute of Management. $<$ https://disser.spbu.ru/files/disser2/1085/disser/8mFtWLb820.pdf> (2020, June, 18). [in Russian].

17. Smokovich, M. (2015). Administrativnaya yustitsiya v voprose diskretsionnykh polnomochiy [Administrative justice in the issue of discretionary powers]. Sudebno-yuridicheskaya gazeta [Judicial-legal newspaper], 46 (314), 13 $<$ https://sud.ua/ru/news/sud-info/84051-administrativnaya-yustitsiya-v-voprose-diskretsionnikh-polnomochij-4c1b25> (2020, June, 18). [in Ukrainian]. 